\title{
In vivo Covalent Binding of Chemicals to DNA as a Short-Term Test for Carcinogenicity
}

\author{
W. K. Lutz and Ch. Schlatter \\ Institute of Toxicology, Federal Institute of Technology and University of Zürich, \\ CH-8603 Schwerzenbach, Switzerland
}

\begin{abstract}
The determination of a covalent binding of radioactive chemicals to DNA in intact mammalian organisms is proposed as a short-term test for carcinogenicity. The effectiveness of covalent binding to rat liver DNA correlates well with the hepatocarcinogenicity known from long-term bioassays. The binding indices range over more than five orders of magnitude between the strongest hepatocarcinogen aflatoxin $B_{1}$ and the limit of detection of a binding with 100 $\mu \mathrm{Ci}{ }^{14} \mathrm{C}$-labelled chemical. The order of magnitude of binding is therefore a surprisingly good quantitative measure for carcinogenicity. The pattern of DNA binding sites is important especially for small alkylating agents where the determination of total binding might indicate a higher carcinogenic potency than is actually observed.
\end{abstract}

Key words: DNA-Binding - Carcinogen - Short-term Carcinogenicity Test Aflatoxin $B_{1}$ - Aflatoxin $M_{1}$ - Toluene - Tritiated Water.

\section{Introduction}

It is now widely accepted that the induction of tumors by organic chemicals involves a covalent binding of these chemicals or one of their metabolites to DNA of the target organs (Irving, 1973; Lawley, 1976).

This covalent interaction can be measured in intact mammalian organisms with the use of radioactively labelled chemicals and could be used as the basis of a shortterm test for carcinogenicity.

\section{Materials and Methods}

The standard protocol for this binding assay involves

1. Administration of the radioactive compound. Rats are used most commonly and the route of administration should preferably be the same as the one of human exposure. 
2. Waiting for absorption and metabolism (a few hours to one day).

3. Isolation of DNA from the organs of interest. Liver is taken in most studies because it contains all the enzymes necessary for a metabolic activation of the compounds and yields plenty of DNA.

4. Determination of the radioactivity on the DNA as a measure for bound chemical.

For a comparison of the effectiveness of covalent DNA-binding of different compounds, the damage to DNA is expressed per unit dose according to the formula for a 'Covalent Binding Index, CBI':

$$
\begin{aligned}
\mathrm{CBI} & =\frac{\text { damage to DNA }}{\text { dose }} \\
& =\frac{\text { Micromole Chemical bound per Mole DNA Phosphate }}{\text { Millimole Chemical administered per kg body weight }}
\end{aligned}
$$

\section{Resuits}

More than 80 compounds have already been investigated on their effectiveness of covalent binding to DNA in vivo (Lutz, 1979), and Table 1 gives a selection of literature data of CBI of hepatocarcinogens of various potency. It is evident that a striking correlation exists between the DNA-binding of these compounds and the carcinogenic properties known from long-term bioassays. Between the CBI of the strongest known hepatocarcinogen aflatoxin $\mathbb{B}_{1}$ and our limit of detection with $100 \mu \mathrm{Ci}{ }^{14} \mathrm{C}$-labelled chemical there are more than 5 orders of magnitude.

Table 2 summarizes our own results with chemicals of controversial or weak carcinogenicity:

Aflatoxin $M_{1}$ is a metabolite of the potent hepatocarcinogen aflatoxin $B_{1}$, and is secreted in an appreciable amount in the milk of cows which have been fed aflatoxin

\begin{tabular}{|c|c|c|c|c|}
\hline Compound & Route & Time (h) & $\mathrm{CBI}$ & Reference \\
\hline \multicolumn{5}{|l|}{ Strong hepatocarcinogens } \\
\hline $\begin{array}{l}\text { Aflatoxin } B_{1} \\
\text { Dimethylnitrosamine }\end{array}$ & $\begin{array}{l}\text { i.p. } \\
\text { i.p. }\end{array}$ & $\begin{array}{l}6 \\
4\end{array}$ & $\begin{array}{r}16,500 \\
6,500\end{array}$ & $\begin{array}{l}\text { Garner, } 1975 \\
\text { Pegg, } 1977\end{array}$ \\
\hline \multicolumn{5}{|l|}{ Moderate hepatocarcinogens } \\
\hline $\begin{array}{l}\text { 2-Acetylaminofluorene } \\
N \text {-Nitrosopyrrolidine }\end{array}$ & $\begin{array}{l}\text { i.p. } \\
\text { p.o. }\end{array}$ & $\begin{array}{l}16 \\
12\end{array}$ & $\begin{array}{l}560 \\
170\end{array}$ & $\begin{array}{l}\text { Goodman, } 1976 \\
\text { Lijinsky, } 1976\end{array}$ \\
\hline \multicolumn{5}{|l|}{ Weak hepatocarcinogens } \\
\hline $\begin{array}{l}\text { Vinyl chloride } \\
\text { 4-Dimethylaminoazobenzene } \\
\text { Urethane }\end{array}$ & $\begin{array}{l}\text { inhal. } \\
\text { i.p. } \\
\text { i.p. }\end{array}$ & $\begin{array}{l}24 \\
24 \\
24\end{array}$ & $\begin{array}{r}240 \\
10 \\
37\end{array}$ & $\begin{array}{l}\text { Bolt, } 1976 \\
\text { Dingman, } 1967 \\
\text { Prodi, } 1970\end{array}$ \\
\hline Limit of detection with $100 \mu \mathrm{Ci}{ }^{14} \mathrm{C}$ & & & $\simeq 0.1$ & Lutz, $1977 b$ \\
\hline
\end{tabular}

Table 1. Correlation of hepatocarcinogenicity of chemicals to their covalent binding to rat liver DNA 
Table 2. Effectiveness of covalent binding to rat liver DNA

\begin{tabular}{|c|c|c|c|c|}
\hline Compound & Route & Time $(h)$ & $\mathrm{CBI}$ & Reference \\
\hline \multicolumn{5}{|l|}{ Strong hepatocarcinogens } \\
\hline $\begin{array}{l}\text { Aflatoxin } \mathrm{B}_{1} \\
\text { Aflatoxin } \mathrm{M}_{1}\end{array}$ & $\begin{array}{l}\text { p.o. } \\
\text { p.o. }\end{array}$ & $\begin{array}{l}6 \\
6\end{array}$ & $\begin{array}{r}10,000 \\
1,600\end{array}$ & \\
\hline Carcinogens, but not hepatocarcinogens & & $\quad \therefore$ & & \\
\hline $\begin{array}{l}\text { Benzo(a)pyrene } \\
\text { (after enzyme induction) } \\
\text { Benzene }\end{array}$ & $\begin{array}{l}\text { i.p. } \\
\text { i.v. } \\
\text { inhal. }\end{array}$ & $\begin{array}{l}50 \\
16 \\
10\end{array}$ & $\begin{array}{l}10 \\
3.6-19.3 \\
1.7\end{array}$ & $\begin{array}{l}\text { Lutz, } 1978 \\
\text { Viviani, } 1978 \\
\text { Lutz, } 1977 \mathrm{a}\end{array}$ \\
\hline \multicolumn{5}{|l|}{ Doubtful or non-carcinogens } \\
\hline $\begin{array}{l}\text { Ethinyloestradiol } \\
\text { Oestrone } \\
\text { Toluene } \\
\text { Saccharin }\end{array}$ & $\begin{array}{l}\text { p.o. } \\
\text { p.o. } \\
\text { inhal. } \\
\text { p.o. }\end{array}$ & $\begin{array}{c}8 \\
8 \\
5 \\
50 \\
\text { bladder DNA }\end{array}$ & $\begin{aligned} & 1.5 \\
& 1.1 \\
\leq & 0.04 \\
< & 0.005 \\
< & 0.05\end{aligned}$ & $\begin{array}{l}\text { Jaggi, } 1978 \\
\text { Jaggi, } 1978 \\
\text { Lutz, } 1977 \mathrm{~b} \\
\text { Lutz, } 1977 \mathrm{~b}\end{array}$ \\
\hline \multicolumn{5}{|l|}{ Control } \\
\hline Tritium from tritiated water & p.o. & $12-48$ & $0.3-1$ & \\
\hline
\end{tabular}

$\mathrm{B}_{1}$ containing diets. Only rare information is available on its carcinogenicity from long-term bioassays and our binding studies show that aflatoxin $M_{1}$ must be classified as a strong hepatocarcinogen.

Ethinyloestradiol is used in some contraceptive drugs which are suspected to produce adenomas of the liver in very low yield. The binding found from this chemical is very low and almost equal to that of benzene, which is not known to induce liver tumors after very high dosage. The damage of liver DNA by ethinyloestradiol is therefore on such a low level that it would be premature to accuse this drug of hepatocarcinogenicity, this all the more as its natural parent compound, oestrone, has an almost equal CBI and circulates in the body in a much higher concentration during a pregnancy.

Saccharin has been reported to induce bladder tumors in male rats fed with a life-long diet containing 5 per cent saccharin. Saccharin is chemically inert and is not metabolized so that a covalent reaction with DNA is highly improbable. Indeed, we did not find any radioactivity on the DNA of liver or bladder after administration of ${ }^{35} \mathrm{~S}$-labelled saccharin on a limit of detection which is two million times below the binding of aflatoxin $B_{1}$. We therefore conclude that saccharin is not a typical chemical carcinogen. The bladder tumors found are rather due to secondary effects on the bladder epithelium from the very high doses used.

Toluene is an example of a compound which is considered safe although we could detect a minute DNA-binding which is about 40 times lower than that of benzene. This ratio adequately reflects the differences in their oncogenic activities and the damage to DNA by toluene is probably on such a low level that it does not lead to a tumor within the life span of the animal. 


\section{Discussion}

In performing such assays it is of crucial importance to exclude all radioactive contamination by rigorous purification of DNA. Noncovalent binding (physicochemical complex formation, intercalation) must be determined in control experiments, and the biosynthetical incorporation of tritium from tritiated water into DNA (Tabie 2) must also be accounted for. Tritiated water can be formed from tritiated compounds by spontaneous exchange or by enzymatic oxidations.

Non-linear dose-binding relationships and time-dependence of the binding reflect pharmacokinetic complications and DNA repair processes. These could have an influence on the CBI but the effects seem to be rather small: More than ten literature references are available for the binding of dimethylnitrosamine (DMNA) to rat liver DNA. Male and female rats of various strains were used, doses ranged from $0.25-30 \mathrm{mg} / \mathrm{kg}$, and the time lag between administration of DMNA and isolation of DNA was between $4 \mathrm{~h}$ and 14 days. Despite this wide range of experimental conditions all the CBI lie between 1400 and 7100 . On the basis of any of these experiments performed, DMNA would have been called a potent hepatocarcinogen.

From binding studies with methylating agents it is known that the exact site of methylation is critical for an assessment of the carcinogenicity, and that the type of chemical reactivity determines the pattern of DNA alkylation. The measurement of total binding as is proposed by this assay might therefore yield too high a CBI for a given carcinogenicity. This is shown by methyl methanesulphonate which ranks with the moderate hepatocarcinogens "due to a CBI of 270-560 (O'Connor, 1973; Swann, 1968) although it is only very weakly hepatocarcinogenic. There is therefore no doubt that the DNA binding pattern or the mutagenic potency of the DNA damage must also be evaluated, especially for small alkyl residues.

\section{References}

Bolt, H. M., Kappus, H., Kaufmann, R., Appel, K. E., Buchter, A., Bolt, W.: Metabolism of ${ }^{14} \mathrm{C}$-vinyl chloride in vitro and in vivo. INSERM Symposia Series 52, 151-164 (1976)

Dingman, C. W., Sporn, M. B.: The binding of metabolites of aminoazo dyes to rat liver DNA in vivo. Cancer Res. 27, Part 1, 938-944 (1967)

Garner, R. C., Wright, C. M.: Binding of $\left[{ }^{14} \mathrm{C}\right]$ aflatoxin $\mathrm{B}_{1}$ to cellular macromolecules in the rat and hamster. Chem.-Biol. Interact. 11, 123-131 (1975)

Goodman, J. I., Trosko, J. E., Yager, J. D., Jr.: Studies on the mechanism of inhibition of 2-acetylaminofluorene toxicity by butylated hydroxytoluene. Chem.-Biol. Interact. 12, 171-182 (1976)

Irving, C. C.: Interaction of chemical carcinogens with DNA. In: Methods in Cancer Research. H. Busch (ed.), Vol. VII, p. 189-244. New York, London: Academic Press 1973

Jaggi, W., Lutz, W. K., Schlatter, C.: Covalent binding of ethinylestradiol and estrone to rat liver DNA in vivo. Chem.-Biol. Interact. 23, 13-18 (1978)

Lawley, P. D.: Carcinogenesis by alkylating agents. In: Chemical Carcinogens, ACS Monograph. C. E. Searle (ed.), Vol. 173, p. 83-244. Washington, D. C.: American Chemical Society 1976

Lijinsky, W.: Interaction with nucleic acids of carcinogenic and mutagenic N-nitroso compounds. Progr. Nucl. Acid Res. Mol. Biol. 17, 247-269 (1976)

Lutz, W. K., Schlatter, C.: Mechanism of the carcinogenic action of benzene: Irreversible binding to rat liver DNA. Chem.-Biol. Interact. 18, 241-245 (1977a)

Lutz, W. K., Schlatter, C.: Saccharin does not bind to DNA of liver or bladder in the rat. Chem.-Biol. Interact. 19, 253-257 (1977b) 
Lutz, W. K., Viviani, A., Schlatter, C.: Nonlinear dose-response relationship for the binding of the carcinogen benzo(a)pyrene to rat liver DNA in vivo. Cancer Res. 38, 575-578 (1978)

Lutz, W. K.: Mutation Res., review in press (1979)

O'Connor, P. I., Capps, M. J., Craig, A. W.: Comparative studies of the hepatocarcinogen N,Ndimethylnitrosamine in vivo: Reaction sites in rat liver DNA and the significance of their relative stabilities. Brit. J. Cancer 27, 153-166 (1973)

Pegg, A. E., Alkylation of rat liver DNA by dimethylnitrosamine: Effect of dosage on $\mathrm{O}^{6}$-methylguanine levels. J. Natl. Cancer Inst. 58, 681-687 (1977)

Prodi, G., Rocchi, P., Grilli, S.: In vivo interaction of urethane with nucleic acids and proteins. Cancer Res. 30, 2887-2892 (1970)

Swann, P. F., Magee, P. N.: Nitrosamine-induced carcinogenesis. The alkylation of nucleic acids of the rat by $\mathrm{N}$-methyl-N-nitrosourea, dimethylnitrosamine, dimethyl sulphate and methyl methanesulphonate. Biochem. J. 110, 39-47 (1968)

Viviani, A., Lutz, W. K.: Modulation of the in vivo covalent binding of the carcinogen benzo(a)pyrene to rat liver DNA by selective induction of microsomal and nuclear aryl hydrocarbon hydroxylase activity. In: Mechanism of toxic action on some target organs. Arch. Toxicol, Suppl. 2, pp. 285-288. Berlin, Heidelberg, New York: Springer 1979 